\title{
Synthesis, Characterization and Biological Activity of Sodium Barbitone-Group-VIII Metals (viz. Ni(II), Pd(II) and Pt(II)) Complexes
}

\author{
Fatma S. M. Hassan*, Wafaa S. Kuran, Asmaa A. Ibrahim, Farouk A. Adam \\ Chemistry Department, Faculty of Science, Aswan University, Aswan, Egypt \\ Email: *Fatma_smh@yahoo.com
}

How to cite this paper: Hassan, F.S.M., Kuran, W.S., Ibrahim, A.A. and Adam, F.A. (2020) Synthesis, Characterization and Biological Activity of Sodium Barbitone-GroupVIII Metals (viz. Ni(II), Pd(II) and Pt(II)) Complexes. Open Journal of Inorganic Nonmetallic Materials, 10, 1-14. https://doi.org/10.4236/ojinm.2020.101001

Received: January 2, 2020

Accepted: January 28, 2020

Published: January 31, 2020

Copyright ( 2020 by author(s) and Scientific Research Publishing Inc. This work is licensed under the Creative Commons Attribution International License (CC BY 4.0).

http://creativecommons.org/licenses/by/4.0/

\section{(c) (i) Open Access}

\begin{abstract}
This work aims to characterize, synthesize and evaluate the biological activity of sodium barbitone and their metal chelates $\mathrm{Ni}(\mathrm{II}), \mathrm{Pd}(\mathrm{II})$ and $\mathrm{Pt}(\mathrm{II})$. The new synthesized metal chelates are investigated by elemental analysis, IR, mass spectra, thermal analysis and biological activity. Square planer structure of the prepared complexes obtained from the result of analysis. The antibacterial and antifungal of sodium barbitone ligand and its conforming metal chelates were screened against bacterial species Gram positive (Staphylococcus aureus), Gram negative bacteria (Escherichia coli) and fungi Aspergillus flavus and Candida albicans fungi. Ampicillin and amphotericin were used as references for antibacterial and antifungal studies. The activity data show that the platinum group metals chelates have activity data show that some of the platinum group metals (viz. $\mathrm{Pt}(\mathrm{II})$ and $\mathrm{Pd}(\mathrm{II})$ ) chelates have a promising biological activity comparing to sodium barbitone parent free ligand against bacterial and fungal species.
\end{abstract}

\section{Keywords}

Sodium Barbitone, Group VIII Metals, Transition Metals Complexes, Spectroscopic Analyses, Thermal Analysis, Biological Activity

\section{Introduction}

Sodium barbitone 5,5-diethyl barbiturate derived from barbituric acid belongs to the family of 2,4-pyrimidione, is prepared by the neutralization of an aqueous solution of lactam with sodium hydroxide and then precipitating the salt by the addition of alcohol (Scheme 1). Sodium barbitone plays an important role in pharmaceutical applications it is a category of drugs that have varied applica- 
tions such as sedatives, hypnotics and anticonvulsants under an assortment of conditions and is also employed for anesthesia [1] [2].

Sodium barbital solutions have also been used as $\mathrm{pH}$ buffers for biological research, e.g., in immunoelectrophoresis or in fixative solutions [3] [4]. As barbital is a controlled substance, barbital-based buffers have largely been replaced by other substances [5].

The coordination chemistry of organotransition-metal complexes which have biologically active ligands has attracted tremendous interest over the years. The study of this complexes enable us understanding the role of these ligands in biological systems, in many biological systems compounds which containing pyrimidine ring play an important role, where they exist in nucleic acids, several vitamins, coenzymes and antibiotics [6] [7]. The nucleic acid is related to antimetabolites used in anticarcinogenic chemotherapy [8]. In recent years, the metal complexes of pyrimidine widely taught owing to their great variety of biological activity ranging from antimalarial, antibacterial, antitumoral, antiviral activities etc. [9]-[15].

The manufacture of plastics and pharmaceuticals products used barbituric acid. Phenobarbital (5-ethyl-5-phenylbarbituric acid) is the drug used most commonly for convulsive disorders and is the drug of choice for infants and young children [16].

Barbiturates have a wide range of medicinal applications and have ability to coordinate with transition metals through one or both deprotonated nitrogen and carbonyl oxygen atoms, synthesis of their metal complexes has attracted our attention to synthesize and characterize barbitone complexes with nickel and some of the platinum group metals [Pd(II) and $\mathrm{Pt}(\mathrm{II})]$.

\section{Experimental}

\subsection{Reagents and Materials}

In this study, the chemicals used are of highest purity available, it included sodium barbitone, $\mathrm{NiCl}_{2} \cdot 6 \mathrm{H}_{2} \mathrm{O}$ and $\mathrm{Pd}\left(\mathrm{C}_{4} \mathrm{H}_{6} \mathrm{O}_{4}\right)$; which are purchased from Aldrich and $\mathrm{K}_{2} \mathrm{PtCl}_{4}$; is a gift from Professor Paul G. Pringle of Bristol University, UK. All are used without further purification. The solvents such as absolute ethanol, methanol, acetone and DMF were purchased from Sigma and are spectroscopic pure. De-ionized water was collected from all glass equipment and used in all preparations.<smiles>C=CC1(CC)C(=O)NC(=O)NC1=O</smiles>

Scheme 1. Synthesis of $\mathrm{Na}$ [Hdebarb]. 


\subsection{Instrumentation}

Weights measurement was performed by using Sensitive analytical balance [0.0001 g, SCALTEC (Germany)]. Stirring and heating were performed by using magnetic stirrer theromostated hot plate (VELPEurope). Automatic pipette is used to take very small volumes of solvents. Melting points were detected in capillary tube using (Gallen Kamp) and elemental microanalysis measurements were performed in the National Research Center Cairo for $\mathrm{C}, \mathrm{H}$ and $\mathrm{N}$.

The infrared spectra were measured using a Perkin Elmer FTIR type in the wave number region $4000-400 \mathrm{~cm}^{-1}$. The electron impact (EI) mass spectra MS at $70 \mathrm{ev}$ of the tested compounds has been done using Shimadzu GC-MS-Qp 1000 PX quadruple mass spectrometer. Thermal analysis (TGA and DTG) were carried out in dynamic nitrogen atmosphere $\left(20 \mathrm{~m} / \mathrm{min}^{-1}\right)$ with heating rate of $10^{\circ} \mathrm{C} \mathrm{min}^{-1}$ using conventional thermal analyzer (Shimadzu system of DTA-50 and 30 series TG-50). The molar magnetic susceptibility was measured on powdered samples using the Faraday method. The diamagnetic corrections were made by Pascal's constant and $\mathrm{Hg}\left[\mathrm{Co}(\mathrm{SCN})_{4}\right]$ was used as a calibrant.

\subsection{Methods}

\subsubsection{Synthesis of $\left[\mathrm{Ni}\left(\mathrm{C}_{8} \mathrm{H}_{11} \mathrm{~N}_{2} \mathrm{O}_{3}\right) \mathrm{Cl} \cdot \mathrm{H}_{2} \mathrm{O}\right] \mathbf{8} \mathrm{H}_{2} \mathrm{O}$}

Sodium 5,5-diethyl barbiturate ligand $(2.47 \mathrm{~g}, 0.011 \mathrm{~mol})$ was dissolved in least amount of bidistilled water, then added to $\mathrm{NiCl}_{2} \cdot 6 \mathrm{H}_{2} \mathrm{O}(0.95 \mathrm{~g}, 0.003 \mathrm{~mol})$. The total volume was completed to $50 \mathrm{ml}$ using bidistilled water. The reaction mixture was stirred for 60 minutes, a pale green precipitate was appeared, filtered off and washed thoroughly with methanol several times. It was recrystallized from DMF/ethanol mixture, dried in desiccator using $\mathrm{CaCl}_{2}$. Yield 76.71\%, (M.P $\left.310^{\circ} \mathrm{C}-312^{\circ} \mathrm{C}\right)$.

\subsubsection{Synthesis of $\left[\mathrm{Pd}\left(\mathrm{C}_{8} \mathrm{H}_{11} \mathrm{~N}_{2} \mathrm{O}_{3}\right)(\mathrm{ACO}) \cdot \mathrm{H}_{2} \mathrm{O}\right] 4 \mathrm{H}_{2} \mathrm{O}$}

Sodium 5,5-diethyl barbiturate ligand $(0.618 \mathrm{~g}, 0.003 \mathrm{~mol})$ was dissolved in least amount of distilled water, then added to $\mathrm{Pd}\left(\mathrm{CH}_{3} \mathrm{COO}^{-}\right)_{2}(0.224 \mathrm{~g}, 0.001 \mathrm{~mol})$ solution and in acetone. The volume of reaction mixture was completed to $30 \mathrm{ml}$ stirred at room temperature for 60 minutes, dark oily precipitate was resulted. It was filtered off, washed thoroughly with methanol, recrystallized from DMF/ ethanol mixture, dried in desiccator containing $\mathrm{CaCl}_{2}$. Yield 77\%, (decomposed at $308^{\circ} \mathrm{C}$ ).

\subsubsection{Synthesis of $\left[\mathrm{Pt}\left(\mathrm{C}_{8} \mathrm{H}_{11} \mathrm{~N}_{2} \mathrm{O}_{3}\right) \mathrm{CL} \cdot \mathrm{H}_{2} \mathrm{O}\right] 2 \mathrm{H}_{2} \mathrm{O}$}

Sodium 5,5-diethyl barbiturate ligand $(0.618 \mathrm{~g}, 0.003 \mathrm{~mol})$ was dissolved in least amount of distilled water, then it was added to $\mathrm{K}_{2} \mathrm{Pt} \mathrm{Cl}_{4}(0.415 \mathrm{~g}, 0.001 \mathrm{~mol})$. The volume of reaction mixture solution was completed to $15 \mathrm{ml}$ with distilled water. It was stirred at room temperature for 24 hours, an oily green precipitate was appeared it was filtered off and washed thoroughly with distilled water several times, recrystallized from DMF/ethanol mixture, dried in desiccator containing $\mathrm{CaCl}_{2}$. Yield $78 \%$, (decomposed at $\left.320^{\circ} \mathrm{C}\right)$. 


\subsection{Biological Activity}

Modified Kirby-Bauer disc diffusion method [17], has been used to determine the antimicrobial activity of the tested samples. Disc diffusion method for yeast developed by National Committee for VlinicalLaboratory Standards using approved standard method (M44-P). Plates inoculated with filamentous fungi as asprgillus flavus at $25^{\circ} \mathrm{C}$ for 48 hours; Gram (+) bacteria as Staphylococcus aureus; Gram (-) bacteria a Escherichia coli, they were incubated at $35^{\circ} \mathrm{C}-37^{\circ} \mathrm{C}$ for 24 - 28 hours and yeast as Candida albicans incubated at $30^{\circ} \mathrm{C}$ for $24-28$ hours, then the diameters of the inhibition zones were measured in millimeters withslipping calipers of the National Committee for Vlinical Laboratory Standards.

\section{Results and Discussion}

\subsection{Physical Properties and Elemental Analysis}

The elemental analyses data of the given group VIII metals metal chelates considerable with the theoretical values within the limit of experimental mistake; as shown in Table 1.

\subsection{FT-IR Spectroscopy}

The FT-IR data of the free ligand and its corresponding metal chelates are examined and the results are presented in Table 2.

Table 1. Properties of new complexes of molar ratio (1:1) of $\mathrm{Ni}(\mathrm{II}), \mathrm{Pd}(\mathrm{II})$ and $\mathrm{Pt}(\mathrm{II})$.

\begin{tabular}{cccccccc}
\hline Compound & Mol.Wt & Color & M.P ${ }^{\circ} \mathrm{C}$ & $\begin{array}{c}\% \mathrm{C} \\
\text { Calc. } \\
\text { (found) }\end{array}$ & $\begin{array}{c}\% \mathrm{H} \\
\text { Calc. } \\
\text { (found) }\end{array}$ & $\begin{array}{c}\mathrm{N} \% \\
\text { Calc. } \\
\text { (found) }\end{array}$ & $\begin{array}{c}\mu_{\text {eff }} \\
\text { (found }\end{array}$ \\
\hline$\left[\mathrm{Ni}\left(\mathrm{C}_{8} \mathrm{H}_{11} \mathrm{~N}_{2} \mathrm{O}_{3}\right) \mathrm{Cl} \cdot \mathrm{H}_{2} \mathrm{O}\right] 8 \mathrm{H}_{2} \mathrm{O}$ & 439.49 & Pale green & $310-312$ & $21.86(21.79)$ & $6.65(6.64)$ & $6.37(6.30)$ & 0.0 \\
{$\left[\mathrm{Pd}\left(\mathrm{C}_{8} \mathrm{H}_{11} \mathrm{~N}_{2} \mathrm{O}_{3}\right)(\mathrm{ACO}) \cdot \mathrm{H}_{2} \mathrm{O}\right] 4 \mathrm{H}_{2} \mathrm{O}$} & 438.71 & Dark oily & 308 & $27.37(27.43)$ & $5.51(5.54)$ & $6.38(6.5)$ & 0.0 \\
{$\left[\mathrm{Pt}\left(\mathrm{C}_{8} \mathrm{H}_{11} \mathrm{~N}_{2} \mathrm{O}_{3}\right) \mathrm{CL} \cdot \mathrm{H}_{2} \mathrm{O}\right] 2 \mathrm{H}_{2} \mathrm{O}$} & 467.78 & Oily green & 320 & $20.54(20.55)$ & $3.66(3.65)$ & $5.98(5.93)$ & 0.0 \\
\hline
\end{tabular}

$\boldsymbol{\mu}_{\text {eff }}:$ effective magnetic moment.

Table 2. Infrared spectrum data of sodium barbitone and its metal chelates (band maxima in $\mathrm{Cm}^{-1}$ ).

\begin{tabular}{|c|c|c|c|c|c|c|c|c|c|c|}
\hline Compound & $\begin{array}{l}v(\mathrm{C}=\mathrm{O}) \\
\text { amide }(\mathrm{I}) \\
(\mathrm{N}-\mathrm{C}=\mathrm{O})\end{array}$ & $\begin{array}{l}v(\mathrm{NH}) \\
\text { amide }\end{array}$ & $\begin{array}{l}v(\mathrm{C}=\mathrm{O}) \\
\text { carbonyl }\end{array}$ & $v(\mathrm{C}-\mathrm{O})$ & $v(=\mathrm{C}-\mathrm{O}-)$ & $v \mathrm{OH}$ & $v(\mathrm{M}-\mathrm{Cl})$ & $v(\mathrm{M}-\mathrm{O})$ & $v$ ring & $v(\mathrm{M}-\mathrm{N})$ \\
\hline $\begin{array}{l}\text { Sodium barbitone } \\
\left(\mathrm{C}_{8} \mathrm{H}_{11} \mathrm{~N}_{2} \mathrm{O}_{3} \mathrm{Na}\right)\end{array}$ & $2467 w$ & $3182 \mathrm{~s}$ & $1667 \mathrm{~s}$ & $1461 \mathrm{~s}$ & $1164 \mathrm{~m}$ & & - & $\ldots$ & $843 \mathrm{~s}$ & $\ldots$ \\
\hline $\begin{array}{l}{\left[\mathrm{Ni}\left(\mathrm{C}_{8} \mathrm{H}_{11} \mathrm{~N}_{2} \mathrm{O}_{3}\right) \mathrm{Cl} \cdot \mathrm{H}_{2} \mathrm{O}\right] 8 \mathrm{H}_{2} \mathrm{O}} \\
\text { (1) }\end{array}$ & - & $3213 b$ & $1678 \mathrm{~s}$ & $1400 \mathrm{~m}$ & $1165 w$ & $3427 \mathrm{sb}$ & $471 w$ & $618 s$ & $872 \mathrm{~m}$ & $618.30 \mathrm{sb}$ \\
\hline $\begin{array}{l}{\left[\mathrm{Pd}\left(\mathrm{C}_{8} \mathrm{H}_{11} \mathrm{~N}_{2} \mathrm{O}_{3}\right)(\mathrm{ACO}) \cdot \mathrm{H}_{2} \mathrm{O}\right] 4 \mathrm{H}_{2} \mathrm{O}} \\
\text { (2) }\end{array}$ & $2354 w$ & $3234 b$ & $\begin{array}{l}1637 s \\
1681 s\end{array}$ & $1405 \mathrm{~m}$ & $1182 w$ & $3545 \mathrm{sb}$ & - & $\begin{array}{l}438 w \\
549 m\end{array}$ & $770 \mathrm{~m}$ & $549.35 \mathrm{~s}$ \\
\hline $\begin{array}{l}{\left[\mathrm{Pt}\left(\mathrm{C}_{8} \mathrm{H}_{11} \mathrm{~N}_{2} \mathrm{O}_{3}\right) \mathrm{CL} \cdot \mathrm{H}_{2} \mathrm{O}\right] 2 \mathrm{H}_{2} \mathrm{O}} \\
\text { (3) }\end{array}$ & - & $3242 b$ & $\begin{array}{l}1637 \mathrm{~s} \\
1687 \mathrm{~s}\end{array}$ & $1408 \mathrm{~m}$ & $1183 w$ & $3458 \mathrm{mb}$ & $474 \mathrm{w}$ & $\begin{array}{l}471.94 w \\
549 \mathrm{~m}\end{array}$ & $772 \mathrm{~m}$ & $549.246 \mathrm{~m}$ \\
\hline
\end{tabular}

Band property: $\mathrm{s}=$ strong, $\mathrm{m}=$ medium, $\mathrm{w}=$ weak. 
The IR data of metal chelates complexes are given in Table 2 . The IR display various sharp bands in the mid infrared region, clearly indicating the presence of barbital [18]. The strong and broad absorptions bands at 34,583,545 and 3427 in complexes 1, 2 and 3 respectively are due to of lattice water [19]. The insignificant shifts of $v \mathrm{NH}$ in complexes 1-3 as compared to ligand $\left(3182 \mathrm{~cm}^{-1}\right)$ are detected at $3242 \mathrm{~cm}^{-1}(\mathrm{Ni}), 3213 \mathrm{~cm}^{-1}(\mathrm{Pd})$, and $3234 \mathrm{~cm}^{-1}(\mathrm{Pt})$, respectively, probably due to formation of hydrogen bonds. The frequency range of $1637-1687$ $\mathrm{cm}^{-1}$ have mastery over very strong IR and Raman bands arising from carbonyls. The change observed for carbonyl vibrations $v \mathrm{C}=\mathrm{O}$ which in position 4, 6 and $v$ $\mathrm{C}-\mathrm{O}$ which in position 2 Figure 1, diagnostic for its participation in coordination. The $v \mathrm{C}=\mathrm{O}$ in complexes 1 and 3 are observed as two distinct absorptions from 1637 to $1687 \mathrm{~cm}^{-1}$, while in complex 2 absorptions bands at 1637 and 1681 $\mathrm{cm}^{-1}$. The $v \mathrm{C}=\mathrm{O}$ in position 4,6 do not correlate predictably with coordination modes of this group. This may be due to the presence of strong intra or intermolecular hydrogen bonding interactions [20], which affect the carbonyl bands, shifting them to lower frequencies. The $v \mathrm{C}$-O in position 2 also shifted to lower frequencies $\left(14,081,405\right.$, and $1400 \mathrm{~cm}^{-1}$ for complexes 1,2 , and 3, respectively) compared to that of the ligand $\left(1461 \mathrm{~cm}^{-1}\right)$. This indicates that the barbital anions are coordinated to metal via the carbonyl oxygen $\mathrm{O}$ which in position 2. This is further confirmed by the appearance of a medium intensity band at 438 $618 \mathrm{~cm}^{-1}$ in spectra of the complexes, assigned to stretch of M-O [21] Table 2. The comparative studies of FTIR for the free ligand and its corresponding metal chelates prove the proposed structure of the complexes which is shown in Figure 1 .

\subsection{Mass Spectra of Sodium Barbitone Metal Chelates}

The electron impact mass spectra (EI-MS) of the newly prepared complexes are recorded at $70 \mathrm{ev}$ and investigated. The mass spectrum for

$\left[\mathrm{Ni}\left(\mathrm{C}_{8} \mathrm{H}_{11} \mathrm{~N}_{2} \mathrm{O}_{3}\right) \mathrm{Cl} \cdot \mathrm{H}_{2} \mathrm{O}\right] 8 \mathrm{H}_{2} \mathrm{O}$ was recorded and investigated Figure 2.

\subsubsection{Mass Spectrum of $\left[\mathrm{Ni}\left(\mathrm{C}_{8} \mathrm{H}_{11} \mathrm{~N}_{2} \mathrm{O}_{3}\right) \mathrm{Cl} \cdot \mathrm{H}_{2} \mathrm{O}\right] 8 \mathrm{H}_{2} \mathrm{O}$}

The electron ionization (EI-MS) mass spectrum for

$\left[\mathrm{Ni}\left(\mathrm{C}_{8} \mathrm{H}_{11} \mathrm{~N}_{2} \mathrm{O}_{3}\right) \mathrm{Cl} \cdot \mathrm{H}_{2} \mathrm{O}\right] 8 \mathrm{H}_{2} \mathrm{O}$ display a signal at $\mathrm{m} / \mathrm{z}=439.85$ (mole mass = $439.48, \mathrm{RI}=0.8 \%)$ this signal may be referred to the appearance of main molecular formulae ion. Through three parallel pathways this fragment is broken which are presented in Scheme 2.

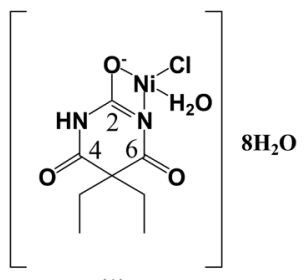

(1)

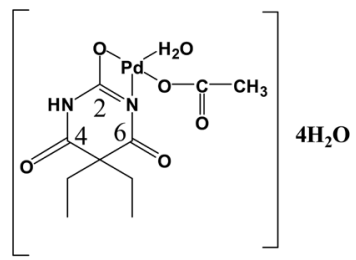

(2)

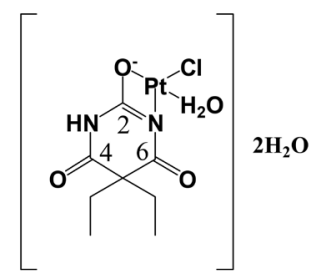

(3)

Figure 1. Proposed structure of the complexes Ni(II), Pd(II) and Pt(II). 


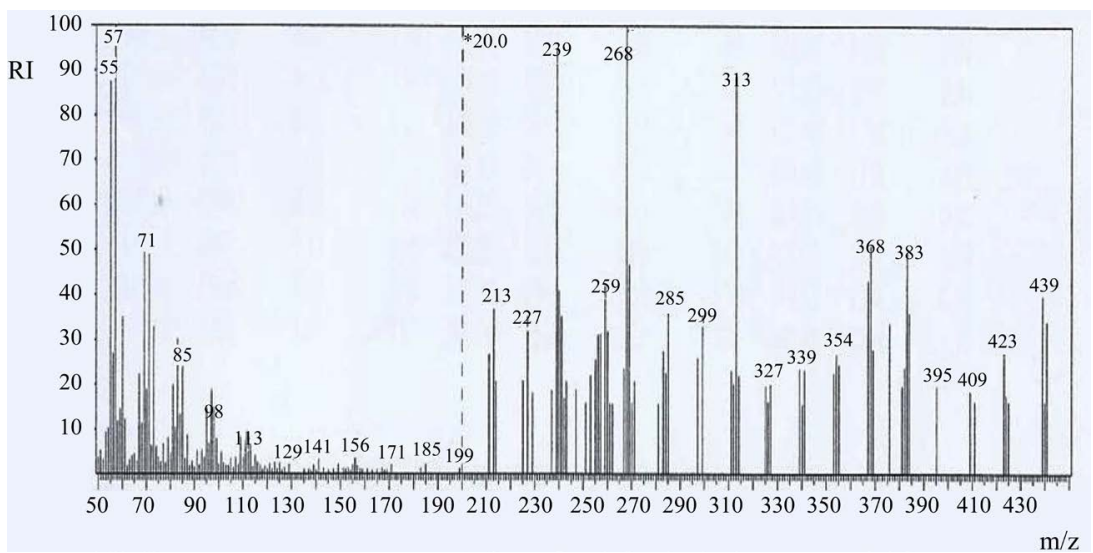

Figure 2. Mass Spectrum of $\left[\mathrm{Ni}\left(\mathrm{C}_{8} \mathrm{H}_{11} \mathrm{~N}_{2} \mathrm{O}_{3}\right) \mathrm{Cl} \cdot \mathrm{H}_{2} \mathrm{O}\right] 8 \mathrm{H}_{2} \mathrm{O}$.

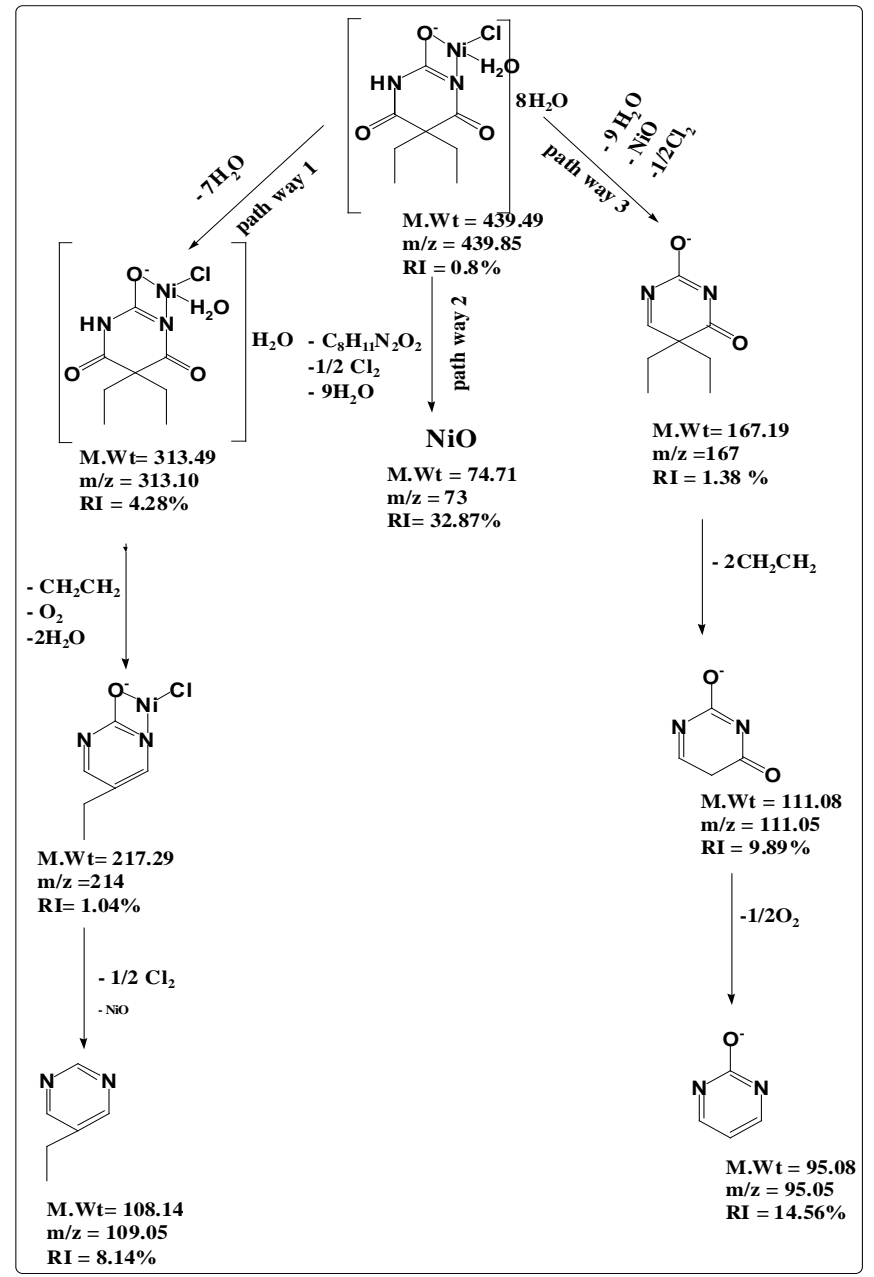

Scheme 2. The mass fragmentation pathways of $\mathrm{Ni}(\mathrm{II})$ chelate with sodium barbitone.

Pathway (1) display fragment ion at $\mathrm{m} / z=313.10$ (mole mass $=313.49, \mathrm{RI}=$ $4.28 \%$ ) due to the rupture of seven molecule of water after that the signal at $\mathrm{m} / \mathrm{z}$ $=214$ (mole mass $=217.29, \mathrm{RI}=1.04 \%)$ due to the loss of $\left(\mathrm{CH}_{2} \mathrm{CH}_{2}, \mathrm{O}_{2}\right.$ and $2 \mathrm{H}_{2} \mathrm{O}$ ). The signal at $\mathrm{m} / \mathrm{z}=109.05$ (mole mass $=108.14, \mathrm{RI}=8.14 \%$ ) due to the 
rupture of $1 / 2 \mathrm{O}_{2}$ and $\mathrm{NiO}$. Pathway (2) shows fragment ions at $\mathrm{m} / \mathrm{z}=73$ (mole mass $=74.71, \mathrm{RI}=32.87 \%)$ attributed to the loss of $\left(\mathrm{C}_{8} \mathrm{H}_{11} \mathrm{~N}_{2} \mathrm{O}_{2}, 1 / 2 \mathrm{Cl}_{2}\right.$ and $9 \mathrm{H}_{2} \mathrm{O}$ ). The third pathway shows fragment ions at $\mathrm{m} / \mathrm{z}=167,111.05$ and 95.05 ( $\mathrm{RI}=1.38 \%, 9.89 \%$ and $14.56 \%$, respectively.); these fragments may be attributed to the loss of $9 \mathrm{H}_{2} \mathrm{O}, \mathrm{NiO}$ and $1 / 2 \mathrm{Cl}_{2}$ followed by the loss of two molecules of Ethene followed by the loss of $1 / 2 \mathrm{O}_{2}$.

\subsubsection{Mass Spectrum of $\left[\mathrm{Pd}\left(\mathrm{C}_{8} \mathrm{H}_{11} \mathrm{~N}_{2} \mathrm{O}_{3}\right)\left(\mathrm{CH}_{3} \mathrm{COO}\right) \mathrm{H}_{2} \mathrm{O}\right] 4 \mathrm{H}_{2} \mathrm{O}$}

The mass fragmentation of $\left[\mathrm{Pd}\left(\mathrm{C}_{8} \mathrm{H}_{11} \mathrm{~N}_{2} \mathrm{O}_{3}\right)\left(\mathrm{CH}_{3} \mathrm{COO}\right) \mathrm{H}_{2} \mathrm{O}\right] 4 \mathrm{H}_{2} \mathrm{O}$ chelate consists of three principal pathways presented in Scheme 3. Pathway 1 display a signal at $\mathrm{m} / \mathrm{z}=348.20(\mathrm{RI}=0.25 \%)$ due to loss of $5 \mathrm{H}_{2} \mathrm{O}$ after that loss $\mathrm{CH}_{3} \mathrm{COOH}$ and $\mathrm{PdO}$ at $\mathrm{m} / \mathrm{z}=167.10$ (mole mass $=168.19, \mathrm{RI}=5.41 \%$ ) followed by loss of molecule of oxygen and two molecule of ethen at $\mathrm{m} / \mathrm{z}=85.15$ (mole mass $=84.12, \mathrm{RI}=36.34 \%$ ). In pathway $(2)$, the fragment at $\mathrm{m} / \mathrm{z}=288.10$ (mole mass $=288.58, \mathrm{RI}=1.24 \%)$ refers to the loss of $5 \mathrm{H}_{2} \mathrm{O}$ and acetic acide. This step is followed by loss of $\mathrm{PdO}, \mathrm{O}_{2}$ and ethen with $\mathrm{m} / \mathrm{z}=111.15$ (mole mass $=110.88$, $\mathrm{RI}=14.01 \%$ ) then loss molecule of $\mathrm{CH}_{2} \mathrm{CH}_{2}$ at $\mathrm{m} / \mathrm{z}=85.15$ (mole mass $=84.12$, $\mathrm{RI}=36.34 \%$ ). Pathway (3) shows signal at $\mathrm{m} / \mathrm{z}=185.15$ (mole mass $=184.95$, RI $=2.97 \%$ ) as loss of five water molecules and palladium acetate followed by loss of $\mathrm{C}_{4} \mathrm{H}_{4} \mathrm{~N}_{2} \mathrm{O}_{3}$ at $\mathrm{m} / \mathrm{z}=57.10$ (mole mass $=56.108, \mathrm{RI}=100 \%$ ).

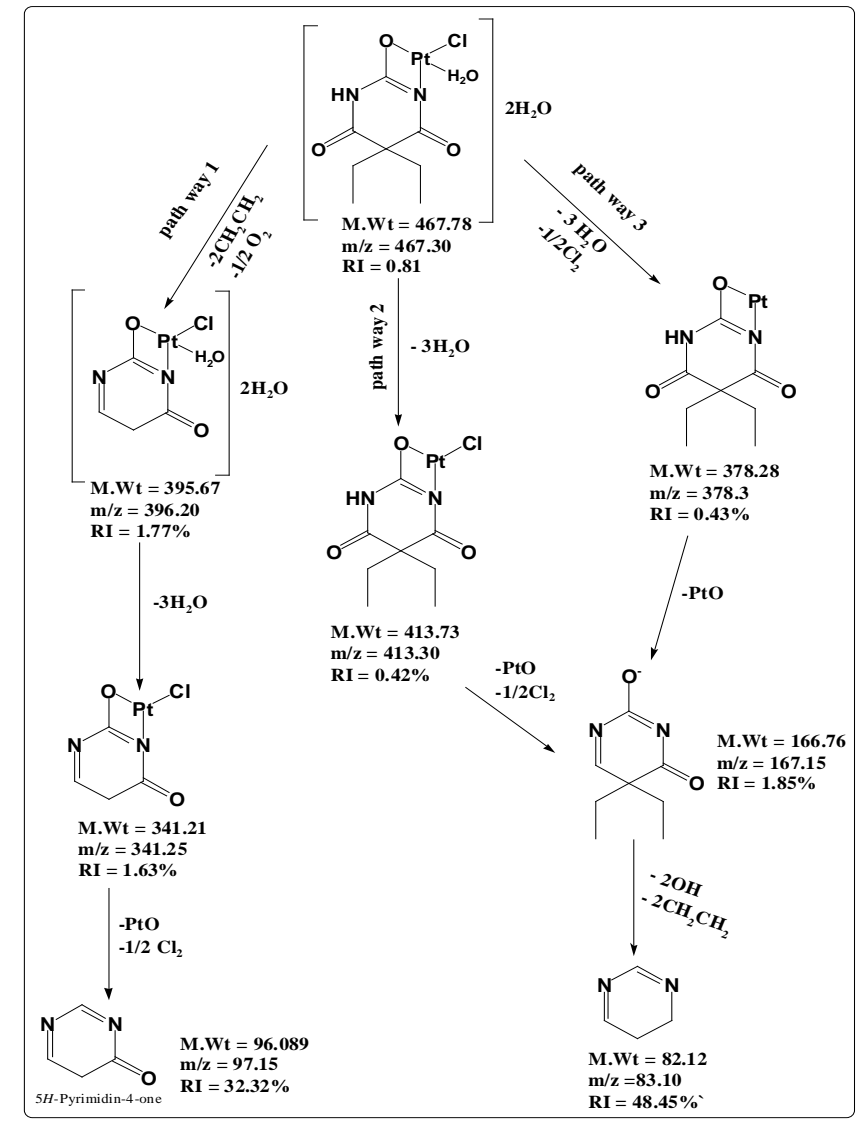

Scheme 3. The mass fragmentation pathways of $\mathrm{Pt}(\mathrm{II})$ chelate with sodium barbitone. 


\subsubsection{Mass Spectrum of $\left[\mathrm{Pt}\left(\mathrm{C}_{8} \mathrm{H}_{11} \mathrm{~N}_{2} \mathrm{O}_{3}\right) \mathrm{Cl} \cdot \mathrm{H}_{2} \mathrm{O}\right] 2 \mathrm{H}_{2} \mathrm{O}$}

The mass fragmentation of $\left[\mathrm{Pt}\left(\mathrm{C}_{8} \mathrm{H}_{11} \mathrm{~N}_{2} \mathrm{O}_{3}\right) \mathrm{Cl} \cdot \mathrm{H}_{2} \mathrm{O}\right] 2 \mathrm{H}_{2} \mathrm{O}$ chelate after ionization of neutral molecule at $70 \mathrm{eV}$ consists of three principal pathways as rationalized in Scheme 4. The signal that appears at $467.30(\mathrm{RI}=0.81 \%)$ may be impute to the apparition of the essential molecular ion. This molecular ion is due to loss of two molecule of ethane and $1 / 2 \mathrm{O}_{2}$ appearance of the signal at $\mathrm{m} / \mathrm{z}=396.20$ (RI $=1.77 \%$ ) followed by the loss of three water molecules appearance of signal at $\mathrm{m} / \mathrm{z}=341.25$ (mole mass $=341.21, \mathrm{RI}=1.63 \%$ ) after that loss of PtO and $1 / 2 \mathrm{Cl}_{2}$ $\mathrm{m} / \mathrm{z}=97.15$ (mole mass $=96.089, \mathrm{RI}=32.32 \%$ ). Pathway II display a signal at $\mathrm{m} / \mathrm{z}=413.30$ (mole mass $=41373, \mathrm{RI}=0.42 \%$ ) due to the loss of $3 \mathrm{H}_{2} \mathrm{O}$, followed by elimination of $\mathrm{PtO}$ and $1 / 2 \mathrm{Cl}_{2}$ with a signal at $\mathrm{m} / \mathrm{z}=167.15$ (mole mass = $166.76, \mathrm{RI}=1.85 \%)$, followed by the loss of $2 \mathrm{OH}$ and two molecule of ethane $\mathrm{m} / \mathrm{z}=83.10$ (mole mass $=82.12, \mathrm{RI}=48.45 \%$ ). Pathway III display a signal at $\mathrm{m} / \mathrm{z}=378.3,167.15$ and $83.10(\mathrm{RI}=0.43 \%, 1.85 \%$ and $48.45 \%)$ due to loss of $1 / 2 \mathrm{Cl}_{2}$ and three coordinated water molecules followed by the loss of PtO after that loss of $2 \mathrm{OH}$ and two molecule of ethane.

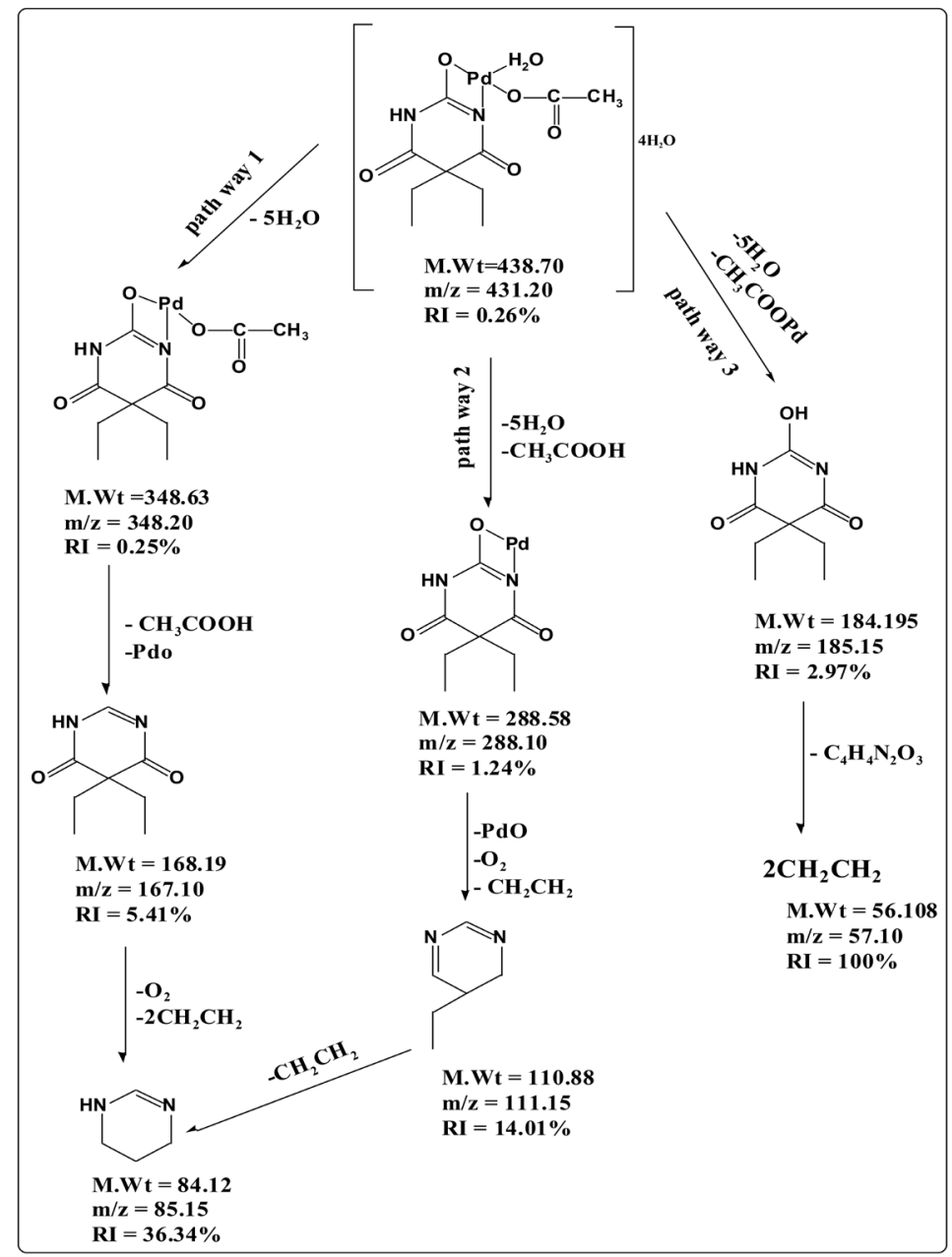

Scheme 4. The mass fragmentation pathways of Pd (II) chelate with sodium barbitone. 


\subsection{Magnetic Moments and Electronic Spectral Data of Metals Complexes}

The UV-Visible spectrum of $\mathrm{Ni}$ (II) complex showed peaks at $260 \mathrm{~nm}(38,461$ $\left.\mathrm{cm}^{-1}\right), 305 \mathrm{~nm}\left(32,786 \mathrm{~cm}^{-1}\right)$ and at $546 \mathrm{~nm}\left(18,315 \mathrm{~cm}^{-1}\right)$ assigned to $\pi \rightarrow \pi^{*}$, LMCT and ${ }^{1} \mathrm{~A} 1 \mathrm{~g} \rightarrow{ }^{1} \mathrm{~A} 2 \mathrm{~g}$ respectively, then confirmed the square-planner environment around nickel (II) ion [22] [23]. The electronic spectrum for the complexes of Pd (II) complex showed the absorption peaks at $246 \mathrm{~nm}\left(40,650 \mathrm{~cm}^{-1}\right)$ $\left(901 \mathrm{molar}^{-1} \mathrm{~cm}^{-1}\right) 305 \mathrm{~nm}\left(32,786 \mathrm{~cm}^{-1}\right)$ and $376 \mathrm{~nm}\left(26,595 \mathrm{~cm}^{-1}\right)$. These transitions belonged to intra-ligand charge transfer, LMCT and ${ }^{1} \mathrm{~A} 1 \mathrm{~g} \rightarrow{ }^{1} \mathrm{~A} 2 \mathrm{~g}$ of $4 \mathrm{~d}^{8}$ configuration of $\mathrm{Pd}(\mathrm{II})$ ion [24]. The electronic spectrum for the $\mathrm{Pt}(\mathrm{II})$ complex exhibited the absorption peaks at $258 \mathrm{~nm}\left(38,759 \mathrm{~cm}^{-1}\right), 305 \mathrm{~nm}\left(32,786 \mathrm{~cm}^{-1}\right)$ and $540 \mathrm{~nm}\left(18,518 \mathrm{~cm}^{-1}\right)$ indicating the $\left(\pi \rightarrow \pi^{*}\right)$ of chromophores; $-\mathrm{C}=\mathrm{N}$-while the second peak is attributed to MLCT respectively [24]. Ni (II), Pd(II) and $\mathrm{Pt}(\mathrm{II})$ were in well-agreement of electronic spectra to confirm their square-planner symmetry as in Table 3.

\subsection{Thermal Analyses}

The TGA thermal analysis data of the synthesized metal chelates are tabulated in Table 4. The thermal decomposition of $\left[\mathrm{Pt}\left(\mathrm{C}_{8} \mathrm{H}_{11} \mathrm{~N}_{2} \mathrm{O}_{3}\right) \mathrm{Cl} \cdot \mathrm{H}_{2} \mathrm{O}\right] 2 \mathrm{H}_{2} \mathrm{O}$ metal chelate as an example occurs through three steps. The first step occurs at temperature $36.56^{\circ} \mathrm{C}-279.23^{\circ} \mathrm{C}$ with mass loss of $7.7 \%$ (calcd.11.5\%). This step may be assigned to the loss of three molecules of water. The second step occurs at temperature range of $279.23^{\circ} \mathrm{C}-350.62^{\circ} \mathrm{C}$ this range may correspond to the removal of $1 / 2 \mathrm{Cl}_{2}$ and $1 / 2 \mathrm{O}_{2}$ with observed mass loss of $7.097 \%$ (calcd. $12.4 \%$ ). The third step occurs at temperature $350.62^{\circ} \mathrm{C}-601.43^{\circ} \mathrm{C}$ with mass loss of $37.7 \%$ (calcd $41.73 \%$ ) this step due to the separation of $\mathrm{C}_{8} \mathrm{H}_{11} \mathrm{~N}_{2} \mathrm{O}$. The total practical mass loss may be $52.59 \%$ (calcd. 55.55\%). The remainder product may be $\mathrm{PtO}$ with practical mass $47.41 \%$ (calcd. $45.13 \%$ ).

The second metal chelate $\left[\mathrm{Pd}\left(\mathrm{C}_{8} \mathrm{H}_{11} \mathrm{~N}_{2} \mathrm{O}_{3}\right)\left(\mathrm{CH}_{3} \mathrm{COO}\right) \mathrm{H}_{2} \mathrm{O}\right] 4 \mathrm{H}_{2} \mathrm{O}$ decomposed through two steps. The first step occurs at range $8.80^{\circ} \mathrm{C}-250.73^{\circ} \mathrm{C}$ with mass loss of $3.489 \%$ (calcd. $4.1 \%$ ). This mass loss may be attributed to the removal of one coordinated water molecule. The second step occurs at range $251.30^{\circ} \mathrm{C}$ $601.74^{\circ} \mathrm{C}$ with mass loss of $66.14 \%$ (calcd 71.14) due to the separation of $\left(4 \mathrm{H}_{2} \mathrm{O}\right.$, $\mathrm{CH}_{3} \mathrm{COOH}$ and $\mathrm{C}_{8} \mathrm{H}_{11} \mathrm{~N}_{2} \mathrm{O}_{2}$ ) leaving $\mathrm{PdO}$ as remainder product with practical mass $30.347 \%$ (calcd. 27.98\%). Three decomposition steps appear in the thermal analysis $\left[\mathrm{Ni}\left(\mathrm{C}_{8} \mathrm{H}_{11} \mathrm{~N}_{2} \mathrm{O}_{3}\right) \mathrm{Cl} \cdot \mathrm{H}_{2} \mathrm{O}\right] 8 \mathrm{H}_{2} \mathrm{O}$ complex. The first one may correspond to the loss of nine molecule of water with mass loss of $20.8 \%$ (calcd. $36.9 \%$ ). The second occurs at $212.76^{\circ} \mathrm{C}-332.96^{\circ} \mathrm{C}$ with a mass loss of $11.8 \%$ (calcd. $15.9 \%$ ), which may be attributed to the loss of ethene and $1 / 2 \mathrm{O}_{2}$. The third step of decomposition $\left(332.96^{\circ} \mathrm{C}-501.77^{\circ} \mathrm{C}\right)$ may be assigned to the loss of $\mathrm{CH}_{3} \mathrm{Cl}, \mathrm{NH}_{3}$ and $1 / 2 \mathrm{O}_{2}$ leaving $\mathrm{NiO}+$ Penta-2,4-diynenitrile as a remainder product with practical mass $31.117 \%$ (calcd. $36.03 \%$ ). To determine the value of the residue, we divide the molecular weight of the residue by the molecular weight of the 
whole complex for example in the case of $\left[\mathrm{Pt}\left(\mathrm{C}_{8} \mathrm{H}_{11} \mathrm{~N}_{2} \mathrm{O}_{3}\right) \mathrm{Cl} \cdot \mathrm{H}_{2} \mathrm{O}\right] 2 \mathrm{H}_{2} \mathrm{O}$ metal chelate $($ mo.t $=467.7768)$ the remainder product $\mathrm{PtO}$ with molecular weight 211.09 to detect the value of residue we perform the following calculation $((211.09 / 467.7768) \times 100)=45.13 \%$.

\section{Biological Activity}

The comparison of the biological activity of the sodium barbitone and its corresponding metal chelates with the standards (ampicillin and amphotericin for antimicrobial and antifungal respectively) towards different organisms was described. The data are recorded in Table 5 and shown in Figure 3. The free ligand and its metal chelates were screened against C.albicans and A.flavas (fungi), S.aureus $\left(\mathrm{G}^{+}\right)$and E.coli $\left(\mathrm{G}^{-}\right)$to assess their potential antimicrobial agent.

Table 3. Electronic spectral data and magnetic moments of metals complexes. (MLCT = Metal-ligand charge transfer).

\begin{tabular}{|c|c|c|c|c|}
\hline Complex & $\begin{array}{c}\text { Observed bands } \\
(\lambda \max / \mathrm{nm}) /\left(v \max / \mathrm{cm}^{-1}\right)\end{array}$ & Assignments & Symmetry & $\mu_{\text {eff }} \mathrm{B} . \mathrm{M}$ \\
\hline \multirow{3}{*}[\mathrm{Ni}(\mathrm{C}_{8}\mathrm{H}_{11}\mathrm{N}_{2}\mathrm{O}_{3})\mathrm{Cl}\cdot\mathrm{H}_{2}\mathrm{O}]{$8 \mathrm{H}_{2} \mathrm{O}$} & $260 / 38,461$ & $\pi \rightarrow \pi^{*}$ & & \\
\hline & $305 / 32,786$ & LMCT & Square planner & 0.0 \\
\hline & $546 / 18,315$ & $1 \mathrm{~A} 1 \mathrm{~g} \rightarrow 1 \mathrm{~B} 1 \mathrm{~g}$ & & \\
\hline \multirow{3}{*}[\mathrm{Pd}(\mathrm{C}_{8}\mathrm{H}_{11}\mathrm{N}_{2}\mathrm{O}_{3})(\mathrm{CH}_{3}\mathrm{COO})\mathrm{H}_{2}\mathrm{O}]{$4 \mathrm{H}_{2} \mathrm{O}$} & $246 / 40,650$ & $\pi \rightarrow \pi^{*}$ & & \\
\hline & $305 / 32,786$ & $\mathrm{n} \rightarrow \pi^{*}$ & Square planner & 0.0 \\
\hline & $376 / 26,595$ & MLCT & & \\
\hline \multirow{3}{*}[\mathrm{Pt}(\mathrm{C}_{8}\mathrm{H}_{11}\mathrm{N}_{2}\mathrm{O}_{3})\mathrm{Cl}\cdot\mathrm{H}_{2}\mathrm{O}]{$2 \mathrm{H}_{2} \mathrm{O}$} & $258 / 38,759$ & $\pi \rightarrow \pi^{*}$ & & \\
\hline & $305 / 32,786$ & $\mathrm{n} \rightarrow \pi^{*}$ & Square planner & 0.0 \\
\hline & $540 / 18,518$ & $1 \mathrm{~A} 1 \mathrm{~g} \rightarrow 1 \mathrm{~B} 2 \mathrm{~g}$ & & \\
\hline
\end{tabular}

Table 4. Thermal analyses data of the newly synthesized $\mathrm{Ni}(\mathrm{II})-\mathrm{Pd}(\mathrm{II})$ and $\mathrm{Pt}(\mathrm{II})$-chelates.

\begin{tabular}{|c|c|c|c|c|}
\hline Compound & TGA. range $\left({ }^{\circ} \mathrm{C}\right)$ & $\%$ Mass loss found (calcd.) & TGA description & Residue \\
\hline \multirow{3}{*}[\mathrm{Ni}(\mathrm{C}_{8}\mathrm{H}_{11}\mathrm{N}_{2}\mathrm{O}_{3})\mathrm{Cl}\cdot\mathrm{H}_{2}\mathrm{O}]{$8 \mathrm{H}_{2} \mathrm{O}$} & $46.40-212.76$ & $20.8(36.8)$ & - the loss of $9 \mathrm{H}_{2} \mathrm{O}$ & \multirow{3}{*}{$\begin{array}{l}\mathrm{NiO}+\mathrm{C}_{5} \mathrm{~N} \\
31.12 \%(36.03 \%)\end{array}$} \\
\hline & $212.76-332.96$ & $11.8(15.9)$ & - the loss of ethene and $1 / 2 \mathrm{O}_{2}$ & \\
\hline & $332.96-501.77$ & $31.117(36.02)$ & - the loss of $\mathrm{CH}_{3} \mathrm{Cl}, \mathrm{NH}_{3}$ and $1 / 2 \mathrm{O}_{2}$ & \\
\hline \multirow{2}{*}[\mathrm{Pd}(\mathrm{C}_{8}\mathrm{H}_{11}\mathrm{N}_{2}\mathrm{O}_{3})(\mathrm{CH}_{3}\mathrm{COO})\mathrm{H}_{2}\mathrm{O}]{$4 \mathrm{H}_{2} \mathrm{O}$} & $8.80-250.73$ & $3.489(4.1)$ & - the loss $\mathrm{H}_{2} \mathrm{O}$ & \multirow{2}{*}{$\begin{array}{l}\mathrm{PdO} \\
30.34 \%(27.98 \%)\end{array}$} \\
\hline & $251.30-601.74$ & $66.14(71.14)$ & $\begin{array}{l}\text { - the loss of }\left(4 \mathrm{H}_{2} \mathrm{O}, \mathrm{CH}_{3} \mathrm{COOH}\right. \\
\left.\text { and } \mathrm{C}_{8} \mathrm{H}_{11} \mathrm{~N}_{2} \mathrm{O}_{2}\right)\end{array}$ & \\
\hline \multirow{3}{*}[\mathrm{Pt}(\mathrm{C}_{8}\mathrm{H}_{11}\mathrm{N}_{2}\mathrm{O}_{3})\mathrm{Cl}\cdot\mathrm{H}_{2}\mathrm{O}]{$2 \mathrm{H}_{2} \mathrm{O}$} & $36.56-279.23$ & $7.75(11.5)$ & - the loss of $3 \mathrm{H}_{2} \mathrm{O}$ & \multirow{3}{*}{$\begin{array}{l}\mathrm{PtO} \\
47.41 \%(45.13 \%)\end{array}$} \\
\hline & $279.23-350.62$ & $7.0921(12.4)$ & - the loss of $1 / 2 \mathrm{Cl}_{2}$ and $1 / 2 \mathrm{O}_{2}$ & \\
\hline & $350.62-601.43$ & $37.73(41.73)$ & - the loss of $\mathrm{C}_{8} \mathrm{H}_{11} \mathrm{~N}_{2} \mathrm{O}$ & \\
\hline
\end{tabular}

Table 5. Antimicrobial activity for sodium baribtone and its metal complexes (10 $\mu \mathrm{g} / \mathrm{disc}$ for each compound).

\begin{tabular}{ccccc}
\hline & \multicolumn{3}{c}{ Inhibition zone diameter (mm/mg sample) } \\
\cline { 2 - 4 } Compound & Gram + bacteria & Gram-bacteria & Fungi & Fungi. \\
Sodium barbitone (ligand) & S. aureus & E. coli & C. albicans & . \\
{$\left[\mathrm{Ni}_{2}\left(\mathrm{C}_{8} \mathrm{H}_{11} \mathrm{~N}_{2} \mathrm{O}_{3}\right) \mathrm{Cl} \cdot \mathrm{H}_{2} \mathrm{O}\right] 8 \mathrm{H}_{2} \mathrm{O}$} & 0.0 & 0.0 & 0.0 & 0.0 \\
{$\left[\mathrm{Pd}\left(\mathrm{C}_{8} \mathrm{H}_{11} \mathrm{~N}_{2} \mathrm{O}_{3}\right)\left(\mathrm{CH}_{3} \mathrm{COO}\right) \mathrm{H}_{2} \mathrm{O}\right] 4 \mathrm{H}_{2} \mathrm{O}$} & 16 & 18 & 20 & 0.0 \\
{$\left[\mathrm{Pt}\left(\mathrm{C}_{8} \mathrm{H}_{11} \mathrm{~N}_{2} \mathrm{O}_{3}\right) \mathrm{Cl} \cdot \mathrm{H}_{2} \mathrm{O}\right] 2 \mathrm{H}_{2} \mathrm{O}$} & 10 & 12 & 12 & 0.0 \\
\hline
\end{tabular}




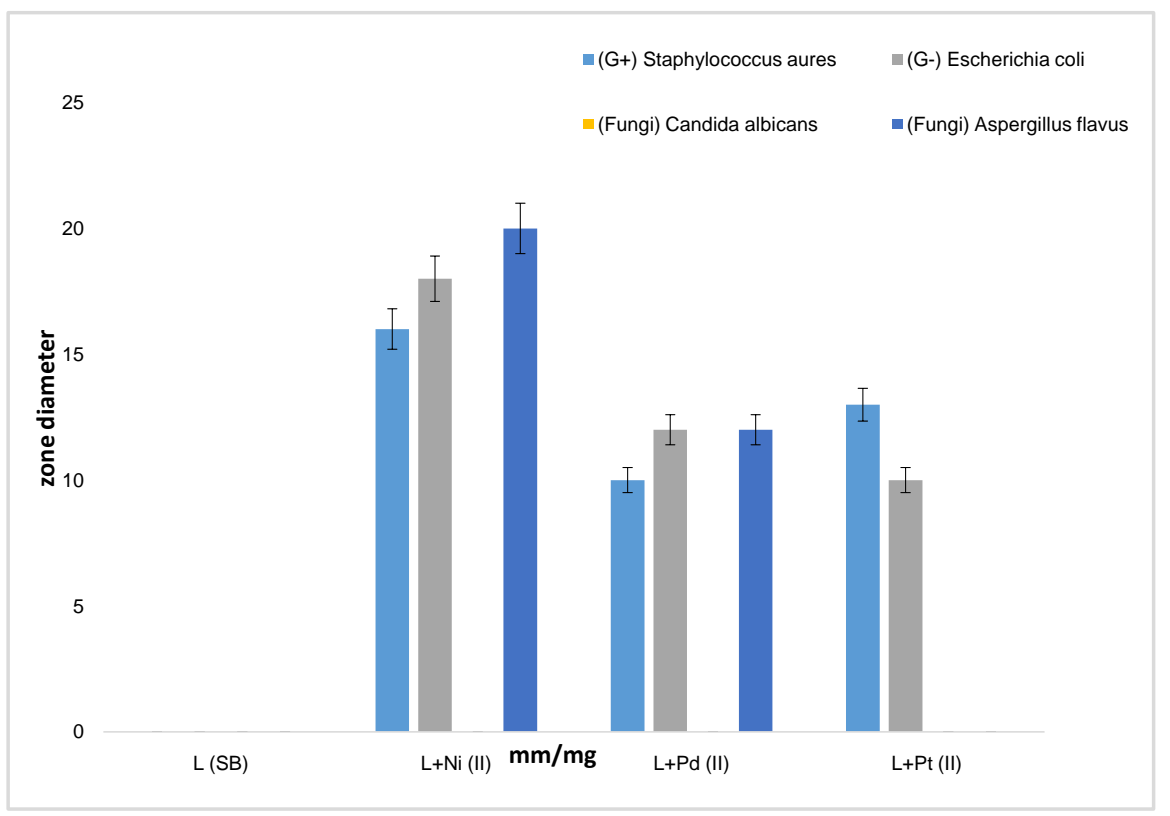

Figure 3. Biological activity of sodium barbitone and its metal complexes.

\section{Sodium Barbitone and Its Complexes}

The metal complexes biological activities (Table 5, Figure 3) are higher than the free ligand towards the gram positive, gram negative bacteria and fungi species. In case of bacteria gram positive, gram negative the $\mathrm{Ni}$ (II) complex show highest bacterial activity than $\mathrm{Pd}(\mathrm{II})$ and $\mathrm{Pt}(\mathrm{II})$ complexes. The antimicrobial activities of the complexes in case of Candida albicans, $\mathrm{Ni}$ (II) shows the highest fungal activity than $\mathrm{Pd}(\mathrm{II})$, but $\mathrm{Pt}(\mathrm{II})$ has no innate activity against Candida albicans. In case of Aspergillus flavus the three metals $\mathrm{Ni}(\mathrm{II}), \mathrm{Pd}(\mathrm{II})$ and $\mathrm{Pt}(\mathrm{II})$ complexes have no activity towards it.

The experimental data presented in Table 5 suggest that the metal complexes of $\mathrm{Ni}(\mathrm{II}), \mathrm{Pd}(\mathrm{II})$ and $\mathrm{Pt}(\mathrm{II})$ are more toxic in comparison to their parent free ligand (sodium barbitone) itself in inhibiting the growth of microorganisms. This inhibiting because of the change in structure of the ligand on coordination to the metals and metal complexes when chelating act as more powerful bacteriostatic agents, so that the growth of microorganisms inhibiting. moreover, the polarity of the metal ion reduces by coordination because of the partial sharing of its positive charge with the donor groups within the chelate ring system formed during the coordination. This would suggest that the chelation could help the ability of the complex to cross a cell membrane and can be explained by Tweedy's chelation theory [25]. The $\mathrm{Ni}(\mathrm{II}), \mathrm{Pd}(\mathrm{II})$ and $\mathrm{Pt}(\mathrm{II})$ complexes show greater antibacterial activity towards bacteria. The variation in the activity of metal complexes against different organisms depends on the impermeability of the microorganism cells or on differences of ribosome of microbial cells [25] [26]. The increase in the antifungal activity of the metal complexes inhibits multiplication process of the microbes by blocking their activity sites. Such increased activity on metal chelation can be explained on the basis of Tweedy's chelation theory. 
While chelation is not the only factor for antimicrobial activity, it is an intricate blend of several aspects such as nature of the metal ion and the ligand, the geometry of the metal complexes, the lipophilicity, steric and pharmacokinetic factors [27].

\section{Conclusion}

In the present study, the free ligand sodium barbitone and it corresponding group VIII metals complexes $\mathrm{Ni}(\mathrm{II}), \mathrm{Pd}(\mathrm{II})$ and $\mathrm{Pt}(\mathrm{II})$ were prepared and structurally identified. The structures of free ligands and its metal chelates are proved by elemental analyses and applying spectroscopic measurements (FT-IR and mass spectra) and confirmed by thermal analyses. On the basis of their analytical data, we propose square planer geometry for metal complexes. The synthesized free ligand are found to be biologically active and their metal complexes showed significantly enhanced antibacterial and antifungal activities against microbial strains in comparison to the free ligand.

\section{Conflicts of Interest}

The authors declare no conflicts of interest regarding the publication of this paper.

\section{References}

[1] Ashnagar, A., Naseri, N.G. and Sheeri, B. (2007) Novel Synthesis of Barbiturates. Chinese Journal of Chemistry, 25, 382-384. https://doi.org/10.1002/cjoc.200790073

[2] Delgado, J.N., Remers, W.A. and Lippincott, J.B. (1991) Wilson and Gisvold's Textbook of Organic Medicinal Pharmaceutical Chemistry. 9th Edition, L. Williams \& Wilkins, Philadelphia, 341, 376, 39.

[3] Kuhlmann, W.D. (2006) Buffer Solutions.

[4] Ruzin, S.E. (1999) Plant Microtechnique and Microscopy. Oxford University Press, Oxford.

[5] Monthony, J.F., Wallace, E.G. and Allen, D.M. (1978) A Non-Barbital Buffer for Immunoelectrophoresis and Zone Electrophoresis in Agarose Gels. Clinical Chemistry, 24, 1825-1827. https://doi.org/10.1093/clinchem/24.10.1825

[6] Hueso-Urena, F., IIIan-Cabeza, N.A., Moreno-Carretero, M.N., Martinez-Martos, J.M. and Ramirez-Exposito, M.J. (2003) Synthesis and Spectroscopic Studies on the New Schiff Base Derived from the 1:2 Condensation of 2,6-Diformyl-4-methylphenol with 5-Aminouracil (BDF5AU) and Its Transition Metal Complexes: Influence on Biologically Active Peptides-Regulating Aminopeptidases. Journal of Inorganic Biochemistry, 94, 326-334. https://doi.org/10.1016/S0162-0134(03)00025-4

[7] Refat, M.S., El-Korashy, S.A. and Ahmed, A.S. (2008) A Convenient Method for the Preparation of Barbituric and Thiobarbituric Acid Transition Metal Complexes. Spectrochimica Acta A, 71, 1084-1094. https://doi.org/10.1016/j.saa.2008.03.001

[8] Tsunoda, A., Shibisawa, M., Yasuda, Y., Nakao, N. and Kusano, K. (1994) Anticancer Research, 14, 2637-2642.

[9] Raper, E.S. (1985) Complexes of Heterocyclic Thione Donors. Coordination Chemistry Reviews, 61, 115-184. https://doi.org/10.1016/0010-8545(85)80004-7 
[10] Casas, J.S., Castellans, E.E., Louce, M.D., Ellena, J., Sanchez, A., Sordo, J. and Taboada, C. (2006) A Gold(I) Complex with a Vitamin K3 Derivative: Characterization and Antitumoral Activity. Journal of Inorganic Biochemistry, 100, 1858-1860. https://doi.org/10.1016/j.jinorgbio.2006.07.006

[11] Campbell, M.J. (1975) Transition Metal Complexes of Thiosemicarbazide and Thiosemicarbazones. Coordination Chemistry Reviews, 15, 279-319. https://doi.org/10.1016/S0010-8545(00)80276-3

[12] Rodriguez-Argüelles, M.C., Ferrari, M.B., Fava, G.G., Pelizzi, C., Tarasconi, P., Albertini, R., Dall'Aglio, P.P., Lunghi, P. and Pinelli, S. (1995) 2,6-Diacetylpyridine bis(thiosemicarbazones) Zinc Complexes: Synthesis, Structure, and Biological Activity. Journal of Inorganic Biochemistry, 58, 157-175. https://doi.org/10.1016/0162-0134(94)00043-A

[13] Casas, J.S., Garcia-Tasende, M.S., Maichel-Mossmer, C., Rodriguez-Argüelles, M.C., Sanchez, A., Sordo, J., Vazquez-Lopez, A., Pinelli, S., Lunghi, P. and Albertini, R. (1996) Synthesis, Structure, and Spectroscopic Properties of Acetato (Dimethyl)(pyridine-2-carbaldehydethiosemicarbazonato)tin(IV) Acetic Acid Solvate, $\left[\mathrm{SnMe}_{2}\right.$ (PyTSC)(OAc)].HOAc. Comparison of Its Biological Activity with That of Some Structurally Related Diorganotin(IV) Bis(thiosemicarbazonates). Journal of Inorganic Biochemistry, 62, 41-55. https://doi.org/10.1016/0162-0134(95)00087-9

[14] Ferrari, M.B., Fava, G.G., Tarasconi, G., Albertini, R., Pinelli, S. and Starcich, R. (1994) Synthesis, Spectroscopic and Structural Characterization, and Biological Activity of Aquachloro(pyridoxal thiosemicarbazone) Copper(II) Chloride. Journal of Inorganic Biochemistry, 53, 13-25. https://doi.org/10.1016/0162-0134(94)80017-0

[15] Koch, U., Attenni, B., Malancona, S., Colarusso, S., Conte, I., Filippo, M.D., Harper, S., Pacini, B., Giomini, C., Thomas, S., Incitti, I., Tomei, L., Francesco, R.D., Altamura, S., Matassa, V.G. and Narjes, F. (2006) 2-(2-Thienyl)-5,6-dihydroxy-4-carboxypyrimidines as Inhibitors of the Hepatitis C Virus NS5B Polymerase: Discovery, SAR, Modeling, and Mutagenesis. Journal of Medicinal Chemistry, 49, 1693 1705. https://doi.org/10.1021/jm051064t

[16] Foye, W.O., Lemke, T.L. and Williams, D.A. (1995) Principles of Medicinal Chemistry. 4th Edition, Williams \& Wilkins, Philadelphia, Vol. 89, 154-180.

[17] Bauer, A.W., Kirby, W.M., Sherris, C. and Turck, M. (1996) Antibiotic Susceptibility Testing by a Standardized Single Disk Method. American Journal of Clinical Pathology, 45, 493. https://doi.org/10.1093/ajcp/45.4_ts.493

[18] Refat, M.S. and Sharshar, T. (2012) Infrared, Raman, 1H NMR, Thermal and Positron Annihilation Lifetime Studies of $\mathrm{Pb}(\mathrm{II}), \mathrm{Sn}(\mathrm{II}), \mathrm{Sb}(\mathrm{III}), \mathrm{Bi}(\mathrm{III})$-Barbital Complexes. Journal of Molecular Structure, 1016, 140-146. https://doi.org/10.1016/j.molstruc.2012.02.047

[19] Babykutty, P.V., Prabhakaran, C.P., Anantaraman, R. and Nair, C.G.R. (1974) Electronic and Infrared Spectra of Biguanide Complexes of the 3d-Transition Metals. Journal of Inorganic and Nuclear Chemistry, 36, 3685-3688. https://doi.org/10.1016/0022-1902(74)80148-X

[20] Yilmaz, V.T., Aksoy, M.S. and Sahin, O. (2009) Different Coordination Modes of 5,5-Diethylbarbiturate in the Copper(II) Complexes with Some Aliphatic Amines: Synthesis, Spectroscopic, Thermal and Structural Studies. Inorganica Chimica Acta, 362, 3703. https://doi.org/10.1016/j.ica.2009.04.026

[21] Timerbaev, A.R., Hartinger, C.G. and Keppler, B.K. (2006) Metallodrug Research and Analysis Using Capillary Electrophoresis. TrAC Trends in Analytical Chemistry, 25, 868-875. https://doi.org/10.1016/j.trac.2006.04.009

[22] Lever, A.B.P. (1984) Inorganic Electronic Spectroscopy. 2nd Edition, Elsevier Science 
Publishers, Amsterdam, 161.

[23] Sylvie, M., et al. (1998) Influence of Disorder on Electronic Excited States: An Experimental and Numerical Study of Alkylthiotriphenylene Columnar Phases. The Journal of Physical Chemistry B, 102, 4697-4710. https://doi.org/10.1021/jp980623n

[24] Farah, M. S., Faisal, M., Nibras, M. and Shaker, C. (2016) International Journal of Pharmaceutics, 6, 47-52.

[25] Tweedy, B.G. (1964) Plant Extracts with Metal Ions as Potential Antimicrobial Agents. Phytopathology, 55, 910-914.

[26] Murukan, B. and Mohanan, K. (2007) Synthesis, Characterization and Antibacterial Properties of Some Trivalent Metal Complexes with [(2-hydroxy-1-naphthaldehyde)3-isatin]-bishydrazone. Journal of Enzyme Inhibition and Medicinal Chemistry, 22, 65-70. https://doi.org/10.1080/14756360601027373

[27] Thankamony, M. and Mohanan, K. (2007) Indian Journal of Chemistry A, 46, 247251. 